\title{
Effect of Nanoscale Zero-Valent Iron Treatment on Biological Reductive Dechlorination: A Review of Current Understanding and Research Needs
}

Center for Environmental Security, The Biodesign Institute, Security and Defense Systems Initiative, Arizona State University, P.O. Box 875904, Tempe, AZ 85287-5904.

* Corresponding author phone: 480-727-0893; fax: 480-965-6603; Email: halden@asu.edu

T.A.B. Present Address: Department of Civil and Environmental Engineering 


\section{Abstract}

Nanoscale zero-valent iron ( $\mathrm{nZVI}$ ) is a strong non-specific reducing agent that is used for in situ degradation of chlorinated solvents and other oxidized pollutants. However, there are

20 significant concerns regarding risks posed by the deliberate release of engineered nanomaterials into the environment, which have triggered moratoria, for example, in the United Kingdom. This critical review focuses on the effect of nZVI injection on subsurface microbial communities, which are of concern due to their important role in contaminant attenuation processes. Corrosion of ZVI stimulates dehalorespiring bacteria, due to the production of $\mathrm{H}_{2}$ that can serve

25 as an electron donor for reduction of chlorinated contaminants. Conversely, lab studies show that $\mathrm{nZVI}$ can be inhibitory to pure bacterial cultures, although toxicity is reduced when $\mathrm{nZVI}$ is coated with polyelectrolytes or natural organic matter. The emerging toolkit of molecular biological analyses should enable a more sophisticated assessment of combined $\mathrm{nZVI/biostimulation} \mathrm{or} \mathrm{bioaugmentation} \mathrm{approaches.} \mathrm{While} \mathrm{further} \mathrm{research} \mathrm{on} \mathrm{the}$ consequences of its application for subsurface microbial communities is needed, $\mathrm{nZVI}$ continues to hold promise as an innovative technology for in situ remediation of pollutants. It is particularly attractive for the remediation of subsurface environments containing chlorinated ethenes because of its ability to potentially elicit and sustain both physical-chemical and biological removal despite its documented antimicrobial properties.

35 Key Words: Nano zero-valent iron, iron nanoparticles, nZVI, reductive dechlorination, Dehalococcoides, chloroethene, groundwater, remediation

\section{Introduction}


The ability to characterize and manipulate materials at scales approaching the atomic level has resulted in a rapid increase in the use of engineered nanomaterials. ${ }^{1}$ In addition to being 40 incorporated into a growing variety of consumer products, nanomaterials have found wide applications in fields such as electronics, optics, medicine, and environmental restoration. ${ }^{2}$ Similar to other emerging technologies (e.g., synthetic biology), engineered nanomaterials face skepticism from those who wonder about the net benefit of these materials in light of their unknown but potentially adverse impacts., ${ }^{3,4}$ One example of a nanotechnology that has

45 received such scrutiny is the use of nanoscale zero-valent iron (nZVI) injections for remediation of contaminated sites. ${ }^{5} \mathrm{nZVI}$ is the foremost example of an engineered nanomaterial that is designed for direct release into the environment, and uncertainties regarding the risks it poses to human health and the environment have led to a moratorium on the use of nanotechnology for environmental remediation in the U.K. pending further research. ${ }^{6}$ This situation presents a

50 paradox: in contrast to many other engineered nanomaterials, nZVI can occur naturally, dissolves readily, and is made of the fourth-most abundant element in the Earth's crust. Fortunately, a growing body of research in nanotoxicology has emerged in parallel to the development of novel nanomaterial applications. Although more research is needed, a basic understanding of the potential mechanisms of nanomaterial toxicity has taken shape. ${ }^{7}$ Using 55 data collected over the past 15 years, it is now possible to begin weighing the benefits of different nanotechnologies against their potential pitfalls. ${ }^{8}$

This review focuses on one aspect of the uncertainty surrounding $\mathrm{nZVI}$ - namely, its effect on the bacterial communities involved in bioremediation of chlorinated solvent pollution.

60 Numerous researchers have documented that exposure to different nanoparticles can lead to 
adverse impacts on microbial life ${ }^{9}$ [and references therein]. In fact, nZVI has even been proposed for use as a bactericide. ${ }^{10-11}$ At the same time, $\mathrm{nZVI}$ is known to create conditions supportive of growth and activity of hydrogenotrophic bacteria involved in the bioattenuation of chlorinated subsurface pollutants ${ }^{12-14}$. Given that as of 2009 bioremediation was the most 65 commonly used method for remediation of contaminated soil and groundwater, ${ }^{15}$ it is thus attractive and important to examine both the positive and negative aspects of $\mathrm{nZVI}$ amendments to the microbial ecology of subsurface environments.

Zero-valent iron nanoparticles can have been speculated and are known to act synergistically 70 with microorganisms responsible for anaerobic dehalogenation of chlorinated organics, with the principal role played being that of an additional source of $\mathrm{H}_{2}$, the microbes' preferred electron donor. ${ }^{12-14,16-17}$ While this relationship has been demonstrated in laboratory studies for microscale zero-valent iron used in permeable reactive barriers, the results of recent studies using nanoscale ZVI are mixed. A more nuanced understanding of the interaction between $\mathrm{nZVI}$

75 and dehalorespiring bacteria is expected to result in improved remedial design and thus better and superior remedial outcomes. Whereas nZVI may impact a variety of pollutants and bioremediation agents, its effect on reductively dechlorinating facultative and strict anaerobic bacteria is of particular interest, due to the high prevalence of chloroethene contamination in global drinking water resources and the fact that these organisms are dependent upon negative 80 oxidation-reduction potentials and $\mathrm{H}_{2}$ as an electron donor. The goal of this review is to analyze the implications of $\mathrm{nZVI}$ treatment on biological reductive dechlorination and identify critical areas for further research. 


\section{Background}

85 It is well known that improper disposal of hazardous wastes has led to widespread contamination of soil and groundwater with chlorinated ethenes and other anthropogenic pollutants including oxidized metals and inorganic anions. Although significant progress has been made in remediating contaminated sites during the past two decades, the number of sites yet to be addressed remains high. The U.S. EPA estimates that there are approximately 300,000

90 contaminated sites remaining in the U.S., with a projected total cleanup cost of more than $\$ 200$ billion over the next twenty years. ${ }^{18}$ Clearly, there is a need for innovative cleanup technologies that are faster and more cost-effective than established methods. At the same time, the remediation industry is facing a growing mandate to reduce the greenhouse gas emissions

resulting from its operations. ${ }^{19} \mathrm{~A}$ result of these two trends is the gradual and ongoing shift

95 away from active, ex situ remediation technologies that transfer contaminated media to the surface for subsequent treatment. Such techniques are highly energy-intensive and are associated with significant emissions of greenhouse gases. Poised to take their place are a variety of emerging technologies that are passive and can be conducted in situ, i.e., within the contaminated subsurface environment. ${ }^{20}$ Advantages of these in situ methods often include a

100 reduction in operating costs, energy usage, environmental disruption, and, in the ideal case, even time to site closure. ${ }^{21}$ This shift towards greater reliance on in situ methods coincides with the emergence of both zero-valent iron and bioremediation as popular remedial technologies.

\section{Zero-Valent Iron}



use in permeable reactive barriers (PRBs). The PRB is a passive in situ remediation technology designed to degrade or immobilize contaminants as they are carried with natural groundwater flow through the barrier. ${ }^{22,23,24}$ A variety of reactive media have been utilized in PRBs, including zeolites, compost, activated carbon, and limestone. However, granular or microscale zero-valent iron is by far the most common. Reactive barriers constructed from ZVI detoxify many contaminants, most notably chlorinated solvents, through redox reactions in which the reduction of the contaminant is coupled to the oxidation of elemental iron.

The potential simplicity and low operating costs of PRBs have made them an attractive option

115 for site cleanup. Despite the advantages of this technology, it does have a number of drawbacks. ${ }^{25}$ These include (i) the high capital cost of PRBs, (ii) their relative inflexibility compared to more established methods such as pump and treat, (iii) the difficulty in addressing contamination at depths greater than approximately $30 \mathrm{~m}$ below ground surface due to constructability issues, ${ }^{23}$ and (iv) the fact that PRBs are useful only as a tool for dissolved plume control and not for source zone reduction because they can only treat contaminants present in the aqueous phase.

Nano Zero-valent Iron. The limitations of PRBs led to the development of nZVI, which has been the focus of much research in recent years. In comparison to granular or microscale iron, nZVI 125 has a higher density of reactive surface sites and can be deployed with greater flexibility in the subsurface. Multiple studies have demonstrated the ability of nanoscale ZVI particles to reduce 
chlorinated solvents, ${ }^{26,27}$ polychlorinated biphenyls $(\mathrm{PCBs}),{ }^{27,}{ }^{28}$ heavy metals, ${ }^{29}$ pesticides $^{30}$ and energetic compounds, ${ }^{30}$ as well as the inorganic anions perchlorate and nitrate. ${ }^{30}$ However, the majority of research has been directed towards the detoxification of chlorinated organics. In

130 laboratory studies the reaction of nZVI with chloroethenes is reported to occur at rates up to two orders of magnitude greater than with microscale ZVI, with production of fewer toxic intermediates. ${ }^{26}$ Moreover, nZVI treatment has been shown to react with PCB congeners that were unaffected by microscale iron. ${ }^{28}$ Contaminant degradation rates can be increased and the range of amenable contaminants broadened by doping nZVI with a noble metal catalyst such as 135 palladium $(\mathrm{Pd}) .{ }^{31}$ The increased reactivity of $\mathrm{nZVI}$ is predominantly a function of its large specific surface area. ${ }^{32}$ Moreover, the small size of nZVI makes it well suited to injection into the subsurface to form in situ reactive zones. ${ }^{32}$ While the reactivity, lifetime, and transport of nZVI have been studied in depth and reviewed recently ${ }^{33}$, the likely effects of nZVI on subsurface microbial communities are still not fully understood. Before addressing the potential effects of $140 \mathrm{nZVI}$ on dechlorinating microorganisms, it is first necessary to review the redox chemistry of this material in the context of its transport and retention/interfacial behavior in porous media.

$\mathrm{Fe}^{0}$ Chemistry. In aqueous environments, zero-valent iron is readily oxidized, releasing two electrons as shown below:

$\mathrm{Fe}_{(\mathrm{s})}^{0} \rightarrow \mathrm{Fe}^{2+}{ }_{(\mathrm{aq})}+2 \mathrm{e}^{-}$ 
The standard electrode potential $\left(\mathrm{E}^{\circ}\right)$ of the reaction in Eqn. (1) is $-0.44 \mathrm{~V}^{34}$. $\mathrm{Fe}^{0}$ commonly forms redox couples with several electron acceptors of environmental relevance. For example, when present in oxic environments, such as the vadose zone or shallow groundwater, $\mathrm{Fe}^{0}$ is oxidized to ferrous ion according to the following reaction:

$2 \mathrm{Fe}_{(\mathrm{s})}^{0}+4 \mathrm{H}^{+}+\mathrm{O}_{2(\mathrm{aq})} \rightarrow 2 \mathrm{Fe}^{2+}+2 \mathrm{H}_{2} \mathrm{O}$

155 The standard electrode potential of the $\mathrm{Fe}^{0} / \mathrm{O}_{2}$ couple is $+0.71 \mathrm{~V}$ at $25^{\circ} \mathrm{C}$, which indicates that the reaction is thermodynamically favorable. ${ }^{34}$ As a result, ZVI consumes dissolved oxygen in groundwater. In oxygen-limited conditions typically found in deeper aquifers or near readily biodegradable contaminant plumes, the reaction of $\mathrm{Fe}^{0}$ with water is more important:

Although anoxic corrosion of ZVI is less thermodynamically favorable than its reaction with oxygen, it still has the effect of consuming the $\mathrm{Fe}^{0}$ core and producing precipitates on the $\mathrm{ZVI}$ surface. Notably, corrosion of ZVI results in the release of hydroxide ions and production of $\mathrm{H}_{2}$.

Ferrous iron produced by corrosion of ZVI can be subsequently oxidized biologically or abiotically to ferric iron, a reaction that can also drive the reduction of anionic subsurface 
contaminants. However, under typical groundwater conditions, it is more common for amorphous iron (oxy)hydroxides or carbonates to precipitate on the particle surface. ${ }^{35,36}$ Over 170 time these amorphous precipitates are converted into various crystalline phases, of which magnetite $\left(\mathrm{Fe}_{3} \mathrm{O}_{4}\right)$ predominates. Depending on the anions present and dissolved oxygen content, other phases including maghemite $\left(\mathrm{Fe}_{2} \mathrm{O}_{3}\right)$, vivianite $\left(\mathrm{Fe}_{3}\left(\mathrm{PO}_{4}\right)_{2} \bullet 8 \mathrm{H}_{2} \mathrm{O}\right)$, schwertmannite $\left(\mathrm{Fe}^{3+} 16 \mathrm{O}_{16}\left(\mathrm{OH}, \mathrm{SO}_{4}\right)_{12-13} \bullet 10-12 \mathrm{H}_{2} \mathrm{O}\right)$ may also form ${ }^{37}$. These precipitates can form a passivating layer that slows electron transfer from the zero-valent iron core, although this effect varies 175 between the different precipitate species.

Zero-valent iron also reacts with various contaminant molecules. The overall equation for the reaction of $\mathrm{ZVI}$ and a chlorinated organic molecule $\mathrm{RCl}$ is as follows. ${ }^{25}$

$$
\mathrm{Fe}_{(\mathrm{s})}^{0}+\mathrm{RCl}+\mathrm{H}^{+} \rightarrow \mathrm{Fe}^{2+}+\mathrm{RH}+\mathrm{Cl}^{-}
$$

Reductive dechlorination reactions such as Eqn. (4) proceed via electron transfers from the iron to the organic molecule at the iron surface. When carried out to completion, this process ultimately yields chloride ions and non-toxic ethene or ethane gas. The two main mechanisms 185 responsible for ZVI-mediated reductive dechlorination are hydrogenolysis and reductive 8 elimination. ${ }^{38,39}$ During hydrogenolysis, each chlorine molecule that is removed and released into solution as chloride is replaced by a hydrogen atom, resulting in a net input of one proton and two electrons. ${ }^{39}$ In this way, higher chlorinated ethenes, such as perchloroethene (PCE) and trichloroethene (TCE), are sequentially dechlorinated to dichloroethene (DCE), vinyl chloride 
190 (VC), and the non-toxic end products ethene and ethane. Conversely, 6 -elimination involves the concurrent removal of two chlorine atoms and the production of acetylene, which is promptly transformed to ethene and ethane. It has been shown that $b$-elimination is likely to dominate over hydrogenolysis during abiotic reduction of chlorinated ethenes by $\mathrm{ZVI}{ }^{14,39}$.

195 The distinction between mechanisms is important because of the different transformation products that are generated by the two different pathways. Bioremediation of chlorinated ethenes such as PCE and TCE is notorious because of its tendency to "stall out" before achieving complete dechlorination of the parent compounds ${ }^{40}$, resulting in the accumulation of undesirable transformation products, primarily DCE and less frequently VC, both of which are regulated contaminants. Although certain mixed cultures and isolates have been shown to degrade TCE to the trans- and 1,1-DCE isomers in laboratory studies, ${ }^{41,42} 43,44,45$ cis-DCE is the isomer that commonly predominates. VC is a known human carcinogen that is more toxic than either TCE or PCE. ${ }^{46}$ The fact that $\mathrm{nZVI}$ can degrade chloroethenes to the desired end products with little accumulation of cis-DCE or VC ${ }^{16,47}$ is a distinct advantage.

In addition to degradation of chlorinated organics, ZVI also can be applied for the treatment of other contaminants by: (i) precipitation of redox-sensitive inorganic anions, ${ }^{35,48}$ (ii) biologically mediated anion reduction (denitrification, sulfate reduction), ${ }^{35,49}$ (iii) and reduction of redoxsensitive metals. ${ }^{29}$ While important, these transformation processes are largely outside the 210 scope of this review. 
Aggregation and Mobility. To effectively treat dissolved groundwater plumes and dense nonaqueous phase liquid (DNAPL) source zone areas, nZVI must be mobile in the subsurface. However, nZVI tends to aggregate quickly to micrometer-sized aggregates, ${ }^{50,51}$ thereby limiting

215 its mobility in saturated porous media and potentially causing decreases in aquifer hydraulic conductivity. ${ }^{52-55}$ It has been shown that ionic strength ${ }^{54,55}$ will decrease nZVI mobility, while natural organic matter (NOM) content ${ }^{56}$ and microbial subsurface biofilms ${ }^{57}$ will increase $\mathrm{nZVI}$ mobility in water-saturated subsurface environments. Several different methods have been developed for limiting aggregation of $\mathrm{nZVI}$ in water and enhancing its mobility in porous media.

220 These methods include suspension of $\mathrm{nZVI}$ in vegetable oil emulsion, ${ }^{58}$ attachment of the particles to anionic carbon supports, ${ }^{51}$ and application of sorbed polymer coatings, $55,59,60,61,62$ or combinations of the above. In some cases these coatings have incorporated hydrophobic moieties to create nZVI particles that will preferentially migrate towards the DNAPL-water interface, ${ }^{58,63}$ albeit the activity of nZVI in the DNAPL has been subject of discussion. ${ }^{12,64}$

Transport of $\mathrm{nZVI}$ is also highly dependent on the injection method, and particles injected using high-pressure techniques are expected to travel farther than those injected via gravity. Filtration theory predicts $\mathrm{nZVI}$ transport distances in the subsurface ranging from a few centimeters up to about $100 \mathrm{~m} . .^{54,56,6566} 67$ Using dissolved oxygen, oxidation/reduction potential, and iron

230 concentration of groundwater as indicators, nanoparticle transport distances of $1.5 \mathrm{~m}$ to $6 \mathrm{~m}$ have been reported. ${ }^{52,68,69}$ The issue of nZVI mobility merits mention here because it will dictate the spatial extent of any stimulation or inhibition of soil bacterial communities. 


\section{Bioremediation}

235 In parallel to the development of nZVI technology, recent research has also led to an improved understanding of biological contaminant degradation processes and the organisms responsible for them. Bioremediation strategies have been shown capable of addressing nearly the entire spectrum of pollutants found at contaminated sites and are gaining increased acceptance.

240 As a result of their common presence in soil and groundwater, much research has focused on the biodegradation of chlorinated solvents ${ }^{40}$ [and references therein]. Because of the electronegative nature of the chlorine atoms contained in these molecules, their carbon-carbon bonds are not typically thermodynamically amenable to oxidative degradation by aerobic microbes. ${ }^{70}$ Instead, they are reductively dechlorinated under anaerobic conditions, where the

245 chloroethene serves as an electron acceptor for the dehalorespiring microorganisms. In contrast to the 8 -elimination reaction that is common in ZVI systems, biological dehalogenation occurs via reductive hydrogenolysis. ${ }^{71}$ In this way, higher chlorinated ethenes such as PCE and TCE can be sequentially dechlorinated to DCE, VC, and ethene. The reductive transformation of chlorinated ethenes is a process of stepwise depletions because higher chlorinated ethenes are 250 the preferential substrate.

Organisms that are capable of dehalorespiration have been identified within the $\delta$ - and $\varepsilon$ Proteobacteria and the low-GC (guanine-cytosine) content Gram-positive bacteria. ${ }^{72}$ However, only Dehalobacter spp. and Dehalococcoides spp. have been shown to be exclusively dependent 255 upon chlorinated organic compounds for respiration. Of the two obligate-halorespiring groups, 
Dehalococcoides spp. alone is known to carry out the entire transformation process from TCE to ethene. Much has been deduced about the first member of this genus since it was first described in $1997,{ }^{73}$ including the fact that it is an obligate hydrogenotroph and performs best within mixed microbial communities that supply it with biogenic $\mathrm{H}_{2}$ and organic cofactors,

260 byproducts of anaerobic organic matter mineralization. ${ }^{74,757677}$ Although Dehalococcoides spp. has been studied extensively in the lab, there is still an incomplete understanding of how its presence and function in the environment change in response to varying environmental conditions. ${ }^{72}$ It has long been established that availability of and competition for electron donors is a key factor, given the oligotrophic conditions that normally prevail in groundwater systems ${ }^{78,}$

26579,80 . Recent work has identified $\mathrm{pH}^{81}$ temperature, ${ }^{82}$ and cocontaminants ${ }^{83}$ as factors that also play an important role.

\section{Effect of Zero-Valent Iron on Biological Reductive Dechlorination.}

There is potential for synergy between granular or nanoscale ZVI treatment [(n)ZVI] and

270 biodegradation of chloroethenes. The highly reducing conditions created by (n)ZVI are precisely the environment in which dechlorinating organisms thrive. Additionally, the corrosion-induced production of $\mathrm{H}_{2}$ by $(n) Z \mathrm{VI}$ is likely to stimulate the growth of halorespirers, for whom hydrogen is the preferred electron donor.

275 PRB-Microbial Interaction. As experience with granular iron PRBs has accumulated, it has become clear that biological processes can have a significant impact on contaminant transformation within the barrier. This principle was not intuitive to early adopters of the PRB 
technology, as it was generally believed that the high $\mathrm{pH}$ environment created by ZVI reactive barriers would inhibit microbial activity. Although corrosion-induced increases in $\mathrm{pH}$ can cause inhibition of anaerobic microbial consortia, ${ }^{84}$ subsequent experience has shown that PRBs often create conditions (i.e., ecological niches) favorable to some amount of biological activity ${ }^{85}$. At one site it was found that the total microbial population inside the PRB was 1 to 3 orders of magnitude higher than background levels as determined by analysis of phospholipid fatty acids and DNA. ${ }^{86}$ Several lab studies have demonstrated enhanced contaminant removal using combined microscale ZVI and microbial systems, with $\mathrm{H}_{2}$ from ZVI corrosion supporting biological degradation of chloromethanes, ${ }^{87,88} \mathrm{TCE}^{71}$ nitrate $^{89}$ perchlorate ${ }^{90,91}$ and energetic materials such as RDX (hexahydro-1,3,5-trinitro-1,3,5-triazine). ${ }^{84}$ Another microbially mediated reaction that was observed in a microscale ZVI system is immobilization of uranium by sulfatereducing bacteria. ${ }^{92}$

However, it is possible that biological activity in iron PRBs may cause decreased performance. For instance, the colonization of a PRB by dechlorinating bacteria may result in transformation of some TCE via less desirable reduction pathways, i.e., production of VC. ${ }^{71}$ Biologically mediated mineral precipitation ${ }^{35}$ or excessive biomass growth could reduce the porosity of the barrier and 295 thus its hydraulic conductivity, thereby causing groundwater to circumvent the treatment zone. The role of biological processes in PRBs has been recently reviewed. ${ }^{20}$

nZVI-Microbe Interaction. Many of the factors influencing the biogeochemistry of iron PRBs will presumably play a role in the interaction between $\mathrm{nZVI}$ and bacteria. Corrosion of $\mathrm{nZVI}$ and 
subsequent production of $\mathrm{H}_{2}$ can be expected to have a stimulatory effect on the obligate hydrogenotrophs that are responsible for biological reductive dechlorination, possibly eliminating the need for addition of external electron donors such as lactate when the particles are coated with a carbon polymer. ${ }^{93}$ It is also possible that nZVI could reduce the concentration of chloroethenes below threshold toxicity levels for dechlorinating organisms in certain areas of

305 the treatment zone..$^{93}$ Liu and Lowry ${ }^{13}$ posited that nZVI could be used to abiotically treat DNAPL source zones, while enhancing biological polishing of the down gradient dissolved plume. Modeling based on experimental data indicated that $\mathrm{H}_{2}$ evolution from nZVI injection could provide $\mathrm{H}_{2}$ concentrations in excess of optimal levels for Dehalococcoides spp. ${ }^{13}$ In order to evaluate the feasibility of these combined abiotic/biotic treatment schemes, it is helpful to 310 understand the effects of $\mathrm{nZVI}$ at the both the single cell and community levels. The following two sections review the developing literature concerning the toxicology of $n Z \mathrm{VI}$ to pure cultures and its effects on halorespiring microbial communities responsible for bioremediation of chloroethenes.

315 Potential for nZVI toxicity. Even the most cursory review of the literature reveals that assessing the ecotoxicity of engineered nanomaterials is complicated. A variety of metallic nanoparticles can act as antimicrobials. ${ }^{94}$ A recent review ${ }^{7}$ cited cell membrane disruption, changes in membrane permeability due to nanoparticle attachment, DNA and protein damage caused by released ions, and apoptosis due to oxidative stress as potential mechanisms of cell death 320 caused by metallic nanoparticles. To date, silver nanoparticles have been the main focus of research due to the well-known antimicrobial properties of silver. ${ }^{94}$ However, recent studies 
have examined the in vitro toxicity of $\mathrm{nZVI}$ towards various pure cultures of microorganisms. ${ }^{10,94-}$ ${ }^{96}$ Table 1 summarizes the findings of these studies.

325 It is difficult to make direct comparisons of the studies represented in Table 1 because of the different experimental protocols that were used (nZVI dose, contact time, etc.). However, each of the studies demonstrated toxicity of nZVI to microorganisms at concentrations at or below those typically used in field applications (<1-10 g-Fe/L). Proposed explanations for the observed toxicity revolve around oxidative stress ${ }^{10,95,96}$ and cell membrane disruption ${ }^{10,94}$ due to reactive 330 oxygen species produced inside the cell or on the bacterial cell wall. ${ }^{97}$ Oxidative stress can result from the production of reactive oxygen species by the reaction of ferrous ions with intracellular oxygen or hydrogen peroxide. ${ }^{94} \mathrm{~A}$ mutant strain of $E$. coli lacking superoxide dismutase activity showed increased sensitivity to $\mathrm{nZVI}$ exposure, ${ }^{95}$ which points to the importance of the oxidative stress mechanism. On the other hand, membrane disruption is presumed to be a result of direct 335 contact between nZVI particles and the cell. One study tested the effect of nZVI on three types of microbes with distinct cell wall architectures: the gram-negative bacteria $P$. fluorescens, the gram-positive bacteria B. subtilis, and the fungus $A$. versicolor. ${ }^{10} P$. fluorescens was most sensitive to $\mathrm{nZVI}$ exposure, followed by $B$. subtilis and $A$. versicolor. Gram-positive bacteria are known to have thicker cell walls than gram-negative bacteria. Fungal cell walls are thicker than 340 either types of bacterial cell walls and contain chitin instead of peptidoglycan. ${ }^{10}$ Thus, this study shows a correlation between sensitivity to nZVI and cell wall architectures, which suggests that either membrane disruption or differential membrane permeability plays a role in nZVI toxicity. Hence, the mechanisms for nZVI toxicity are likely different than those described for other 
metallic nanoparticles (e.g., nanosilver, where the release of ions is the main mechanism for 345 toxicity. ${ }^{98}$ )

Cytotoxicity of nZVI and Fe oxide nanoparticles to Escherichia coli has been shown to vary in proportion to the oxidation state of the iron atoms, with toxicity decreasing with increasing oxidation state. ${ }^{95}$ Iron nanoparticles consisting of nZVI were most toxic, followed by magnetite

$350\left(\mathrm{Fe}^{\mathrm{ii} / \mathrm{iii}}\right)$, and maghemite ( $\left.\mathrm{Fe} \mathrm{iii}^{\mathrm{ii}}\right)$. This finding is consistent with the results of other studies ${ }^{10,94,96,97}$ that showed decreased toxicity as nZVI was exposed to oxygen and surface $\mathrm{Fe}^{0}$ was reduced to Fe-oxide phases. These results suggest that oxidation of the nZVI particle shell in groundwater may reduce its cytotoxicity to $E$. coli over time ${ }^{96}$.

355 It is significant that the majority of the studies listed in Table 1 have utilized bare nZVI lacking polymeric coatings or sorbed NOM. As discussed previously, nZVI injected into the subsurface will typically be treated with one of several types of coatings to prevent aggregation and facilitate dispersal. Moreover, uncoated nZVI injected into an aquifer is likely to rapidly become coated with NOM due to electrostatic attraction. In the same way that these coatings reduce 360 adhesion of $\mathrm{nZVI}$ to aquifer sediments, they may reduce contact between $\mathrm{nZVI}$ and the bacterial cell wall, thus decreasing toxic effects ${ }^{96}$. For this reason the results of assays performed using uncoated nZVI or in media lacking NOM may overestimate toxicity. This point is illustrated clearly by the results of a study that showed inactivation of $E$. coli by one hour exposure to 100 $\mathrm{mg} / \mathrm{L}$ of $\mathrm{nZVI}$ was reduced from 5.2-log to less than 0.2-log when the nZVI was coated with poly(styrene sulfonate), poly(aspartate), or $\mathrm{NOM}^{96}$. It is also conceivable that reduced toxicity in 
the presence of coatings results from the slower release of dissolved $\mathrm{Fe}^{2+}$ from the coated nZVI. Until there is conclusive evidence linking cytotoxicity to either dissolution of nZVI or the nanoparticles themselves, it is difficult to establish the mechanism by which coatings reduce nZVI toxicity.

In addition to the specific modes of toxicity described above, it is possible that injection of nZVI could cause an increase in groundwater $\mathrm{pH}$ that would be inhibitory to dechlorinating microorganisms, which thrive at circumneutral $\mathrm{pH}^{72,81}$ However, because most aquifer environments are sufficiently buffered, a typical nZVI injection is unlikely to cause drastic

375 changes in $\mathrm{pH}^{13}$ This conclusion is supported by field studies that documented no increase in groundwater $\mathrm{pH}$ upon nZVI injection..$^{52,68,99}$ In cases where field injection of nZVI did raise groundwater $\mathrm{pH}$, the increase was limited to one or two units above ambient levels. ${ }^{30,69,99}$ In one instance, ${ }^{99}$ long term monitoring indicated a decrease in $\mathrm{pH}$ of one unit, which can possibly be attributed to biological growth stimulated by reducing conditions created by the nZVI

380 injection. Dilution by natural groundwater flow is expected to limit the spatial and temporal extent of post-injection $\mathrm{pH}$ changes, although data to confirm this expectation is lacking in the literature. Overall, the available field results indicate that inhibition of dechlorinating bacteria by $\mathrm{nZVI-driven} \mathrm{pH}$ changes is probably limited when both processes are juxtaposed because of their contrasting impact on $\mathrm{pH}$. Yet, buffer amendments are likely required for effective removal of 385 TCE near source areas, e.g. DNAPLs, because of the strong impact of microbial removal on the $\mathrm{pH}^{100}$ 
The pure culture studies summarized in Table 1 uniformly suggest that the prospects for combining nZVI with biological treatment are quite poor. Because these tests assessed acute exposure, factors such as microbial adaptation over time were not determined while prolonged exposure is likely to yield different results because of hysteresis. This means that a microbial community that was previously or continuously exposed to nZVI particles will possess a different transcriptome and/or proteome and as a result be less sensitive to the toxic effects of $\mathrm{nZVI}$ than a naive community. In addition, the results of several recent microcosm-scale tests using more representative, mixed microbial cultures are slightly more positive. Table 2 presents a summary of these microcosm tests.

Addition of nZVI caused a number of changes to the microbial ecology of the microcosms used in these studies. These changes included decreases ${ }^{101}$ and increases ${ }^{102}$ in total bacteria levels, 400 alterations in bacterial diversity that were observed qualitatively by denaturing gradient gel electrophoresis (DGGE), ${ }^{102}$ and quantitatively as stimulation ${ }^{102}$ and inhibition ${ }^{101}$ of sulfate reducing bacteria, and stimulation of methanogenic bacteria. ${ }^{102,103}$ Exposure to $\mathrm{nZVI}$ caused decreased dechlorination rates and down-regulation of reductive dehalogenase genes relative to 16 s rRNA. ${ }^{103}$

In one experiment, order of magnitude increases in total bacteria levels compared to controls were attributed to utilization of a biodegradable nZVI coating as a carbon source. This experiment also showed that higher biomass concentrations could be reached despite partial loss of the protective coating. Experimental results showing that stabilized nZVI may remain 
410 active for up to eight months ${ }^{104}$ suggest that such coatings could be designed to serve as a longterm slow release carbon source in addition to their primary function of supplying Fe.

Two of the studies observed decreased TCE degradation rates in batch microcosms containing $\mathrm{nZVI}$ and mixed dechlorinating cultures compared to the cultures alone. ${ }^{93,101}$ One group

415 hypothesized that dechlorinating bacteria were initially inhibited by fresh $\mathrm{nZVI}$, and that the decrease in inhibition observed over time was a result of passivation at the $\mathrm{nZVI}$ surface. ${ }^{93}$ Other researchers observed a decrease in TCE degradation rates with increasing nZVI dosage and a decline in viable bacteria counts at $\mathrm{nZVI}$ doses greater than $0.3 \mathrm{~g} \mathrm{~L}^{-1}{ }^{101}$ Addition of bare $\mathrm{nZVI}$ to a mixed anaerobic culture containing Dehalococcoides spp. was shown to decrease the expression 420 of the reductive dehalogenase genes tce $A$ and $v c r A$ by 97 and 137-fold, respectively, normalized to $16 \mathrm{~S}$ rRNA gene expression. This negative effect was muted and even reversed when a polymer-coated nZVI was used, resulting in a mild ( 3-fold) upregulation of both tceA and $v c r A{ }^{103}$ It should also be noted that evidence from both field ${ }^{52}$ and $\mathrm{lab}^{93,102}$ studies indicate that methanogens may compete with halorespirers for the $\mathrm{H}_{2}$ produced as a result of $n Z V I$ addition, 425 and this, together with the previously discussed species-specific sensitivity to nZVI, are possible explanations for the observed decrease in dechlorination rates.

None of the pure culture or mixed community studies cited above addressed the potential toxicity of Pd in Pd-doped nZVI. While Pd is a known toxicant to aquatic plants, invertebrates, 430 and vertebrates, ${ }^{105}$ there has been little systematic study of its effects on bacteria. Recent work involving production of biogenic Pd-nanoparticles found that exposure to Pd resulted in reduced 
growth of Clostridium pasteurianum, ${ }^{106}$ but not of Shewanella oneidensis. ${ }^{107}$ Due to the large number of studies proposing bimetallic Fe/Pd nanoparticles for use in remediation, further research is needed on the potential toxicity of $\mathrm{Pd}$ to subsurface bacterial communities.

Figure 1 is a conceptual diagram of nZVI injection in the vicinity of a DNAPL source zone. It illustrates the potential spatial distribution of impacts to the subsurface microbial community due to $\mathrm{nZVI}$ injection. Near the injection well, concentrations of both nZVI and TCE are above threshold toxicity levels, leading to significant inhibition of microbial activity. Iron nanoparticle

440 concentration will decrease with increasing distance from the well due to consumption of nZVI and sedimentation of $\mathrm{nZVI}$ in the aquifer material. The TCE concentration profile will also decrease with increasing distance from the source zone. It is in this zone of moderate TCE and nZVI concentrations that biostimulation is likely to occur due to consumption of both corrosionproduced $\mathrm{H}_{2}$ and biodegradable polymer coatings. At some distance down gradient from the

445 injection point the concentration of $\mathrm{nZVI}$ and $\mathrm{H}_{2}$ will become negligible and biostimulation will cease. While growing evidence suggests the likelihood of a scenario such as that shown in Figure 1 , the factors that influence inhibition and stimulation of microorganisms in $\mathrm{nZVI}$ treatment zones are numerous and quite complex. Clearly the scenario outlined here will not hold true in every case, but based on current knowledge, it approximates typical conditions prevailing at 450 many sites.

Molecular methods for assessing the impact of $\mathrm{nZVI}$ to subsurface microbiota. 
To delimit the zones of microbial stimulation and inhibition as shown in Figure 1, further research must be conducted to understand the impact of nZVI on subsurface biological

455 processes. This section reviews the emerging toolkit of molecular biological analyses that can be used to investigate the effect of nZVI treatment on in situ microbiota.

While 16S rRNA-targeting approaches (DGGE, T-RFLP, qPCR, or FISH) are commonly applied in microbial ecology studies, their relevance can in some cases be debated. ${ }^{108}$ Since $16 \mathrm{~S}$ rRNA 460 sequences provide no unambiguous functional information for dechlorinating communities, ${ }^{109}$ they alone cannot be used to determine the treatment strategy of a contaminated site. Nevertheless, 16S rRNA-based techniques can allow site specialists to decipher the global impact of the NZVI injections on the native, biostimulated, or bioaugmented subsurface microbiota. On the other hand, the targeted analysis of functional gene transcripts or products can provide a qualitative and quantitative assessment of the microbial processes that occur at or downstream of the nZVI injection site (Table 3). The resolving power of these molecular analyses can be greatly improved when combined with chemical analysis of the oxidation/reduction potential, dissolved oxygen, and the levels of the contaminants and their dechlorination byproducts (where applicable). Table 3 provides some of the functional genes that have been 470 used previously to study in situ processes and can also be used when screening for the impact of nZVI injections. The question remains how the functional genes should be tracked to provide a maximum of information, reliably, cost-effectively, and swiftly. 
Much of the research performed on soil and aquifer microbiology use traditional PCR-based

475 methods (DGGE, T-RFLP, and qPCR) to inventory the 16S rRNA or functional gene diversity and abundance in remediation sites. Most often total DNA is used as the template for these analyses because the issues with RNA-based analyses in soil are numerous, and have been reviewed. ${ }^{110}$ Nevertheless, new total RNA extraction protocols have been published that aimed to improve both quality and the amount of template material from subsurface samples. ${ }^{111}$

480

Qualitative (DGGE, T-RFLP, pyrosequencing, phylogenetic microarrays) and quantitative (qPCR) analyses can provide complementary information and should therefore both be applied to generate the best possible fingerprint of dechlorinating subsurface microbiota. ${ }^{112}$ However, the principal caveats of qPCR-based quantification of functional genes remain the appropriateness 485 of existing primer pairs and the quantitative relation of functional gene transcripts with the cell number or biomass, because the number of genes (DNA-level) and transcripts (RNA-level) is known to differ between species and strains. Moreover, quantified functional genes have rarely been found to correlate well with functionality. ${ }^{113}$

490 Alternative approaches to PCR-based techniques are the rRNA-targeting Fluorescence In Situ Hybridization (FISH), ${ }^{114}$ Catalized Reporter Deposition (CARD)-FISH, ${ }^{115}$ and microautoradiography (MAR)-FISH, ${ }^{116}$ that can be used to correlate microbial identities to spatial localization or functionality. Albeit powerful techniques in microbial ecology, they are difficult to apply in the field. Nevertheless, when FISH is coupled to flow cytometry (FISH-FC) ${ }^{117}$ using the 495 16S rRNA or functional probes presented in Table 3 as fluorescent probes, functional data that is 
of relevance to remedial managers can be generated rapidly using only a few milliliters of groundwater from downstream monitoring wells. This has only become possible since the flow cytometry companies have developed portable flow cytometers designed for mobile laboratories. Moreover, many complications of the PCR-based techniques are avoided with flow cytometric approaches. There is no need for extracting the cells from the matrix and the data is on a per cell basis and not on a gene-, transcript-, or peptide basis, which can be more straightforward to interpret. Hence, FISH-FC can be used to determine the microbial processes that occur in the subsurface in response to the nZVI injections. It should be noted though that 16S rRNA targeting probes will be more sensitive than the functional genes because of the 505 difference in expression levels, particularly in environmental samples. Depending on the metabolic state and species there are approximately $10^{3}-10^{5}$ ribosomes per cell to which $16 \mathrm{~S}$ rRNA probes can bind. ${ }^{118}$ Yet, detection of Dehalococcoides spp. using FISH will be challenging due to their small cell size and lower ribosome content, particularly under low activity conditions. ${ }^{115}$ Regardless, a suite of traditional flow cytometric microbiology analyses can be 510 performed on the groundwater samples. Among these dye-based methods is the Live/Dead assay that can be used two fluorescent dyes (SYTO9 and propidium iodide) to monitor nZVI toxicity nearly in real-time since the combined incubation and analysis time is only minutes. ${ }^{117}$ Flow cytometry could also help determine the mobility of introduced microbes and their interactions with the soil and other microorganisms in situations where bioaugmentation is 515 applied by quantifying cell counts in surrounding monitoring wells.

While PCR-based, DNA- and RNA-targeting analyses have been shown to be powerful approaches for planktonic and surface attached microorganisms, they are more appropriate for 
soil or aquifer (solid) samples but these sites are extremely difficult to sample. Flow cytometry

520 analysis of groundwater microbiota can circumvent many of the issues that are often encountered using the other molecular techniques (regardless of whether fluorescent probes or dyes are used), but are limited to aqueous samples (and its suspended biomass). Because of this, it is imperative that quantitative relations are established between the surface-attached and the suspended microbiota. Regardless of whether the future research on the interaction

525 between $\mathrm{nZVI}$ and microbiota is based on PCR, protein analysis, FISH, or flow cytometry, it is certain that there will be a central role for metagenomic approaches to unravel the functional diversity of dechlorinating microbiota and to improve primers, probes, and our understanding of the functional relations within the community.

\section{Concluding Remarks}

The increasing use of $\mathrm{nZVI}$ for environmental restoration necessitates a thorough assessment of this technology's potential impacts on microbial processes in the subsurface. Remediation of chlorinated organic pollutants using a combined nZVI - biostimulation approach holds promise, but the weight of the literature suggests that this strategy may only be effective if applied in a

535 manner that limits toxicity to subsurface microbiota. A further understanding of biogeochemical interactions is needed in order to accurately predict the extent of toxic and biostimulatory effects. Future research efforts should include the development of methods suitable for detecting iron nanoparticles in soil and groundwater and to distinguish anthropogenic nanoparticles from naturally occurring ones. This would enable determination of true in situ

540 travel distances and persistence of $\mathrm{nZVI}$ in the subsurface. New nanoparticle detection technologies, when combined with field data on the spatial variability of dechlorinating 
populations, could be used to develop a more detailed model for the interaction between nZVI and soil microbes. Moreover, this would decrease reliance on inexact indicators such as oxidation/reduction potential, dissolved oxygen and dissolved iron, the relative importance of

545 which is unclear. As more is learned about nZVI toxicity mechanisms and how they change as the nanoparticles are oxidized, it should become possible to assess the relative risk of the iron nanoparticles themselves relative to the changes in bulk water chemistry that they produce.

Finally, increased use of new molecular biological tools in both field and laboratory settings should help to elucidate the effect of nZVI on microbial diversity, as well as specific bacterial

550 populations such as Dehalococcoides spp. In summary, this review reveals that there is much evidence suggesting that injection of $\mathrm{nZVI}$ is likely to stimulate biological reductive dechlorination. Yet, the risk of adverse effects to soil and sediment microbial communities and biological attenuation processes is real, and should be taken into consideration whenever nZVI treatment is implemented as a remedial strategy for contaminated subsurface environments.

\section{Acknowledgements}

T.A.B. is supported by a Graduate Research Fellowship from the National Science Foundation. This work was supported in part by Award Numbers R01ES015445 and 1R01ES020889 from the National Institute of Environmental Health Sciences (NIEHS). The content is solely the 560 responsibility of the authors and does not necessarily represent the official views of the NIEHS or the National Institutes of Health (NIH).

\section{References}


1. Nanoscale Science Engineering and Technology Subcommittee; US National Science and 565 Technology Council The National Nanotechnology Initiative: Strategic Plan.

http://www.nano.gov/sites/default/files/pub resource/nni strategic plan 2007.pdf?q=NNI Str ategic Plan 2007.pdf (accessed Sept. 25, 2013).

2. Karn, B.; Kuiken, T.; Otto, M., Nanotechnology and in situ remediation: a review of the 570 benefits and potential risks. Environ. Health Perspect. 2009, 117 (12), 1813-31.

3. Colvin, V. L., The potential environmental impact of engineered nanomaterials. Nat. Biotechnol. 2003, 21 (10), 1166-70.

575 4. Masciangioli, T.; Zhang, W. X., Environmental technologies at the nanoscale. Environ Sci Technol 2003, 37 (5), 102A-108A.

5. Grieger, K. D.; Fjordboge, A.; Hartmann, N. B.; Eriksson, E.; Bjerg, P. L.; Baun, A., Environmental benefits and risks of zero-valent iron nanoparticles ( $\mathrm{nZVI}$ ) for in situ remediation: 580 risk mitigation or trade-off? J. Contam. Hydrol. 2010, 118 (3-4), 165-83.

6. U.K. Department of Trade and Industry. Response to the Royal Society and Royal Academy of Engineering Report: 'Nanoscience and nanotechnologies: applications and uncertainties.

585 http://webarchive.nationalarchives.gov.uk/+/http://www.dti.gov.uk/science/science-ingovt/st policy issues/nanotechnology/page20218.html (accessed Feb 11, 2010).

7. Nel, A. E.; Madler, L.; Velegol, D.; Xia, T.; Hoek, E. M.; Somasundaran, P.; Klaessig, F.; Castranova, V.; Thompson, M., Understanding biophysicochemical interactions at the nano-bio 590 interface. Nat. Mater. 2009, 8 (7), 543-57.

8. Crane, R. A.; Scott, T. B., Nanoscale zero-valent iron: future prospects for an emerging water treatment technology. J. Hazard. Mater. 2012, 211-212, 112-25. 
595 9. Handy, R. D.; von der Kammer, F.; Lead, J. R.; Hassellov, M.; Owen, R.; Crane, M., The ecotoxicology and chemistry of manufactured nanoparticles. Ecotoxicology 2008, 17 (4), 287314.

10. Diao, M.; Yao, M., Use of zero-valent iron nanoparticles in inactivating microbes. Water Res 2009, 43 (20), 5243-51.

11. Chen, Q.; Gao, M.; Li, J.; Shen, F.; Wu, Y.; Xu, Z.; Yao, M., Inactivation and magnetic separation of bacteria from liquid suspensions using electrosprayed and nonelectrosprayed $\mathrm{nZVI}$ particles: observations and mechanisms. Environ. Sci. Technol. 2012, 46 (4), 2360-7.

605

12. Fagerlund, F.; Illangasekare, T. H.; Phenrat, T.; Kim, H. J.; Lowry, G. V., PCE dissolution and simultaneous dechlorination by nanoscale zero-valent iron particles in a DNAPL source zone. J Contam Hydrol 2012, 131 (1-4), 9-28.

610 13. Liu, Y.; Lowry, G. V., Effect of particle age (Fe(0) content) and solution pH on NZVI reactivity: $\mathrm{H}_{2}$ evolution and TCE dechlorination. Environ. Sci. Technol. 2006, 40 (19), 6085-90.

14. Liu, Y.; Phenrat, T.; Lowry, G. V., Effect of TCE concentration and dissolved groundwater solutes on NZVI-promoted TCE dechlorination and H2 evolution. Environ Sci Technol 2007, 41 615 (22), 7881-7.

15. Pandey, J. a. C. A. a. J. R. K., Integrative approaches for assessing the ecological sustainability of in situ bioremediation. FEMS Microbiology Reviews 2009, 33 (2), 324--375.

620 16. Wei, Y. T.; Wu, S. C.; Chou, C. M.; Che, C. H.; Tsai, S. M.; Lien, H. L., Influence of nanoscale zero-valent iron on geochemical properties of groundwater and vinyl chloride degradation: A field case study. Water Res 2010, 44 (1), 131-40. 
17. Xiu, Z. M.; Jin, Z. H.; Li, T. L.; Mahendra, S.; Lowry, G. V.; Alvarez, P. J., Effects of nano625 scale zero-valent iron particles on a mixed culture dechlorinating trichloroethylene. Bioresour Technol 2010, 101 (4), 1141-6.

18. Office of Solid Waste and Emergency Response. Cleaning up the nation's waste sites: markets and technology trends. http://www.epa.gov/tioclu-in.org/marketstudy.

630

19. Ellis, D. E.; Hadley, P. W., Sustainable remediation white paper - integrating sustainable principles, practices, and metrics into remediation projects. Remediation 2009, 19, 5-114.

20. Kalin, R. M., Engineered passive bioreactive barriers: risk-managing the legacy of 635 industrial soil and groundwater pollution. Curr. Opin. Microbiol. 2004, 7 (3), 227-38.

21. Suthersan, S. S.; Payne, F. C., In Situ Remediation Engineering. CRC Press: Boca Raton, FL, 2005.

640 22. Gillham, R. W.; Ohannesin, S. F., Enhanced Degradation of Halogenated Aliphatics by Zero-Valent Iron. Ground Water 1994, 32 (6), 958-967.

23. Interstate Technology \& Regulatory Council. Permeable reactive barriers: lessons learned/new directions; Interstate Technology and Regulatory Council: Washington DC, 2005.

645

24. Scherer, M. M.; Richter, S.; Valentine, R. L.; Alvarez, P. J., Chemistry and microbiology of permeable reactive barriers for in situ groundwater clean up. Crit Rev Microbiol 2000, 26 (4), 221-64.

$65025 . \quad$ Li, X. Q.; Elliott, D. W.; Zhang, W. X., Zero-valent iron nanoparticles for abatement of environmental pollutants: Materials and engineering aspects. Crit. Rev. Solid State and Mat. Sci. 2006, 31 (4), 111-122. 
26. Lien, H. L.; Zhang, W. X., Nanoscale iron particles for complete reduction of chlorinated 655 ethenes. Colloid Surface A 2001, 191 (1-2), 97-105.

27. Wang, C. B.; Zhang, W. X., Synthesizing nanoscale iron particles for rapid and complete dechlorination of TCE and PCBs. Environ. Sci. Technol. 1997, 31 (7), 2154-2156.

660 28. Lowry, G. V.; Johnson, K. M., Congener-specific dechlorination of dissolved PCBs by microscale and nanoscale zerovalent iron in a water/methanol solution. Environ. Sci. Technol. 2004, 38 (19), 5208-16.

29. Ponder, S. M.; Darab, J. G.; Mallouk, T. E., Remediation of $\mathrm{Cr}(\mathrm{VI})$ and $\mathrm{Pb}(\mathrm{II})$ aqueous 665 solutions using supported, nanoscale zero-valent iron. Environ. Sci. Technol. 2000, 34 (12), 25642569.

30. Zhang, W. X., Nanoscale iron particles for environmental remediation: An overview. J. Nanopart. Res. 2003, 5 (3-4), 323-332.

670

31. Lien, H.-L.; Zhang, W.-x., Hydrodechlorination of chlorinated ethanes by nanoscale Pd/Fe bimetallic particles. Journal of environmental engineering 2005, 131 (1), 4-10.

32. Tratnyek, P. G.; Johnson, R. L., Nanotechnologies for environmental cleanup. Nano 675 Today 2006, 1 (2), 44-48.

33. O'Carroll, D.; Sleep, B.; Krol, M.; Boparai, H.; Kocur, C., Nanoscale zero valent iron and bimetallic particles for contaminated site remediation. Advances in Water Resources 2013, 51 (0), 104-122.

680

34. Snoeyink, V. L.; Jenkins, D., Water chemistry. Wiley: New York, 1980. 
35. Gu, B.; Phelps, T. J.; Liang, L.; Dickey, M. J.; Roh, Y.; Kinsall, B. L.; Palumbo, A. V.; Jacobs, G. K., Biogeochemical dynamics in zero-valent iron columns: Implications for permeable reactive barriers. Environmental Science \& Technology 1999, 33 (13), 2170-2177.

36. Matheson, L. J.; Tratnyek, P. G., Reductive dehalogenation of chlorinated methanes by iron metal. Environ. Sci. Technol. 1994, 28 (12), 2045-53.

690 37. Reinsch, B. C.; Forsberg, B.; Penn, R. L.; Kim, C. S.; Lowry, G. V., Chemical Transformations during Aging of Zerovalent Iron Nanoparticles in the Presence of Common Groundwater Dissolved Constituents. Environmental Science \& Technology 2010, 44 (9), 34553461.

695 38. Campbell, T. J.; Burris, D. R.; Roberts, A. L.; Wells, J. R., Trichloroethylene and tetrachloroethylene reduction in a metallic iron-water-vapor batch system. Environ. Toxicol. Chem. 1997, 16 (4), 625-630.

39. Roberts, A. L.; Totten, L. A.; Arnold, W. A.; Burris, D. R.; Campbell, T. J., Reductive elimination of chlorinated ethylenes by zero-valent metals. Environ. Sci. Tech. 1997, 30, 2654 7002659.

40. Bradley, P. M.; Chapelle, F. H., Biodegradation of Chlorinated Ethenes. In In Situ Remediation of Chlorinated Solvent Plumes, SERDP/ESTCP Environmental Remediation Technology: 2010; p 39.

705

41. He, J.; Sung, Y.; Krajmalnik-Brown, R.; Ritalahti, K. M.; Loffler, F. E., Isolation and characterization of Dehalococcoides sp. strain FL2, a trichloroethene (TCE)- and 1,2dichloroethene-respiring anaerobe. Environ. Microbiol. 2005, 7 (9), 1442-1450.

710 42. Ziv-El, M.; Delgado, A. G.; Yao, Y.; Kang, D. W.; Nelson, K. G.; Halden, R. U.; KrajmalnikBrown, R., Development and characterization of DehaloR^2, a novel anaerobic microbial consortium performing rapid dechlorination of TCE to ethene. Appl. Microbiol. Biotechnol. 2011, $92(5), 1063-1071$. 
715 43. Griffin, B. M.; Tiedje, J. M.; Loffler, F. E., Anaerobic microbial reductive dechlorination of tetrachloroethene to predominately trans-1,2-dichloroethene. Environ. Sci. Technol. 2004, 38 (16), 4300-3.

44. Miller, G. S.; Milliken, C. E.; Sowers, K. R.; May, H. D., Reductive Dechlorination of 720 Tetrachloroethene to trans-Dichloroethene and cis-Dichloroethene by PCB-Dechlorinating Bacterium DF-1. Environmental Science \& Technology 2005, 39 (8), 2631-2635.

45. Cheng, D.; Chow, W. L.; He, J., A Dehalococcoides-containing co-culture that dechlorinates tetrachloroethene to trans-1, 2-dichloroethene. The ISME journal 2009, 4 (1), 8872597.

46. Loffler, F. E.; Edwards, E. A., Harnessing microbial activities for environmental cleanup. Curr. Opin. Biotechnol. 2006, 17 (3), 274-284.

$73047 . \quad$ Liu, Y. Q.; Majetich, S. A.; Tilton, R. D.; Sholl, D. S.; Lowry, G. V., TCE dechlorination rates, pathways, and efficiency of nanoscale iron particles with different properties. Environ. Sci. Technol. 2005, 39 (5), 1338-1345.

48. Alowitz, M. J.; Scherer, M. M., Kinetics of nitrate, nitrite, and $\mathrm{Cr}(\mathrm{VI})$ reduction by iron 735 metal. Environ. Sci. Technol. 2002, 36 (3), 299-306.

49. Gandhi, S.; Oh, B. T.; Schnoor, J. L.; Alvarez, P. J. J., Degradation of TCE, Cr(VI), sulfate, and nitrate mixtures by granular iron in flow-through columns under different microbial conditions. Water Res. 2002, 36 (8), 1973-1982.

740

50. Phenrat, T.; Saleh, N.; Sirk, K.; Tilton, R. D.; Lowry, G. V., Aggregation and sedimentation of aqueous nanoscale zerovalent iron dispersions. Environ. Sci. Technol. 2007, 41 (1), 284-290. 
51. Schrick, B.; Hydutsky, B. W.; Blough, J. L.; Mallouk, T. E., Delivery vehicles for zerovalent metal nanoparticles in soil and groundwater. Chem. Mater. 2004, 16 (11), 2187-2193.

52. Henn, K. W.; Waddill, D. W., Utilization of nanoscale zero-valent iron for source remediation - a case study. Remediation 2006, 16, 57-77.

750 53. Kanel, S. R.; Goswami, R. R.; Clement, T. P.; Barnett, M. O.; Zhao, D., Two dimensional transport characteristics of surface stabilized zero-valent iron nanoparticles in porous media. Environ. Sci. Technol. 2008, 42 (3), 896-900.

54. Saleh, N.; Kim, H. J.; Phenrat, T.; Matyjaszewski, K.; Tilton, R. D.; Lowry, G. V., Ionic 755 strength and composition affect the mobility of surface-modified $\mathrm{Fe}(0)$ nanoparticles in watersaturated sand columns. Environ. Sci. Technol. 2008, 42 (9), 3349-3355.

55. Lin, Y. H.; Tseng, H. H.; Wey, M. Y.; Lin, M. D., Characteristics of two types of stabilized nano zero-valent iron and transport in porous media. Science of the Total Environment 2010, $760408(10), 2260-2267$.

56. Johnson, R. L.; Johnson, G. O.; Nurmi, J. T.; Tratnyek, P. G., Natural Organic Matter Enhanced Mobility of Nano Zerovalent Iron. Environ. Sci. Technol. 2009, 43 (14), 5455-5460.

765 57. Lerner, R. N.; Lu, Q.; Zeng, H.; Liu, Y., The effects of biofilm on the transport of stabilized zerovalent iron nanoparticles in saturated porous media. Water Res. 2012, 46 (4), 975-85.

58. Quinn, J.; Geiger, C.; Clausen, C.; Brooks, K.; Coon, C.; O'Hara, S.; Krug, T.; Major, D.; Yoon, W. S.; Gavaskar, A.; Holdsworth, T., Field demonstration of DNAPL dehalogenation using emulsified zero-valent iron. Environ. Sci. Technol. 2005, 39 (5), 1309-1318.

59. Sirk, K. M.; Saleh, N. B.; Phenrat, T.; Kim, H. J.; Dufour, B.; Ok, J.; Golas, P. L.; Matyjaszewski, K.; Lowry, G. V.; Tilton, R. D., Effect of Adsorbed Polyelectrolytes on Nanoscale 
Zero Valent Iron Particle Attachment to Soil Surface Models. Environmental Science \&

60. He, F.; Zhao, D. Y., Preparation and characterization of a new class of starch-stabilized bimetallic nanoparticles for degradation of chlorinated hydrocarbons in water. Environmental Science \& Technology 2005, 39 (9), 3314-3320.

780

61. Saleh, N.; Phenrat, T.; Sirk, K.; Dufour, B.; Ok, J.; Sarbu, T.; Matyiaszewski, K.; Tilton, R. D.; Lowry, G. V., Adsorbed triblock copolymers deliver reactive iron nanoparticles to the oil/water interface. Nano Letters 2005, 5 (12), 2489-2494.

785 62. Phenrat, T.; Saleh, N.; Sirk, K.; Kim, H.-J.; Tilton, R.; Lowry, G., Stabilization of aqueous nanoscale zerovalent iron dispersions by anionic polyelectrolytes: adsorbed anionic polyelectrolyte layer properties and their effect on aggregation and sedimentation. Journal of Nanoparticle Research 2008, 10 (5), 795-814.

790 63. Saleh, N.; Phenrat, T.; Sirk, K.; Dufour, B.; Ok, J.; Sarbu, T.; Matyiaszewski, K.; Tilton, R. D.; Lowry, G. V., Adsorbed triblock copolymers deliver reactive iron nanoparticles to the oil/water interface. Nano Lett. 2005, 5 (12), 2489-2494.

64. Phenrat, T.; Fagerlund, F.; Illangasekare, T.; Lowry, G. V.; Tilton, R. D., Polymer-Modified Fe0 Nanoparticles Target Entrapped NAPL in Two Dimensional Porous Media: Effect of Particle Concentration, NAPL Saturation, and Injection Strategy. Environmental Science \& Technology 2011, 45 (14), 6102-6109.

65. Yang, G. C. C.; Tu, H.-C.; Hung, C.-H., Stability of nanoiron slurries and their transport in 800 the subsurface environment. Sep. Purif. Technol. 2007, 58, 166-172.

66. Phenrat, T.; Kim, H.-J.; Fagerlund, F.; Illangasekare, T.; Lowry, G. V., Empirical correlations to estimate agglomerate size and deposition during injection of a polyelectrolytemodified FeO nanoparticle at high particle concentration in saturated sand. Journal of 805 Contaminant Hydrology 2010, 118 (3-4), 152-164. 
67. Phenrat, T.; Song, J. E.; Cisneros, C. M.; Schoenfelder, D. P.; Tilton, R. D.; Lowry, G. V., Estimating Attachment of Nano- and Submicrometer-particles Coated with Organic Macromolecules in Porous Media: Development of an Empirical Model. Environmental Science \& Technology 2010, 44 (12), 4531-4538.

68. He, F.; Zhao, D.; Paul, C., Field assessment of carboxymethyl cellulose stabilized iron nanoparticles for in situ destruction of chlorinated solvents in source zones. Water Res. 2010, 44 (7), 2360-70.

815

69. Wei, Y. T.; Wu, S. C.; Chou, C. M.; Che, C. H.; Tsai, S. M.; Lien, H. L., Influence of nanoscale zero-valent iron on geochemical properties of groundwater and vinyl chloride degradation: A field case study. Water Res. 2010, 44 (1), 131-40.

820 70. Wohlfarth, G.; Diekert, G., Anaerobic dehalogenases. Curr. Opin. Biotech. 1997, 8 (3), 290-295.

71. Lampron, K. J.; Chiu, P. C.; Cha, D. K., Reductive dehalogenation of chlorinated ethenes with elemental iron: The role of microorganisms. Water Res. 2001, 35 (13), 3077-3084.

72. Tas, N.; van Eekert, M. H.; de Vos, W. M.; Smidt, H., The little bacteria that can diversity, genomics and ecophysiology of 'Dehalococcoides' spp. in contaminated environments. Microb. Biotechnol. 2010, 3 (4), 389-402.

830 73. Maymo-Gatell, X.; Chien, Y.; Gossett, J. M.; Zinder, S. H., Isolation of a bacterium that reductively dechlorinates tetrachloroethene to ethene. Science 1997, 276 (5318), 1568-71.

74. Duhamel, M.; Mo, K.; Edwards, E. A., Characterization of a highly enriched dehalococcoides-containing culture that grows on vinyl chloride and trichloroethene. Appl. Environ. Microbiol. 2004, 70 (9), 5538-45. 
75. Schipp, C. J.; Marco-Urrea, E.; Kublik, A.; Seifert, J.; Adrian, L., Organic cofactors in the metabolism of Dehalococcoides mccartyi strains. Philosophical Transactions of the Royal Society B: Biological Sciences 2013, 368 (1616).

76. Smidt, H.; de Vos, W. M., Anaerobic microbial dehalogenation. Annu Rev Microbiol 2004, 58, 43-73.

77. Ziv-El, M.; Popat, S. C.; Parameswaran, P.; Kang, D. W.; Polasko, A.; Halden, R. U.; 845 Rittmann, B. E.; Krajmalnik-Brown, R., Using electron balances and molecular techniques to assess trichoroethene-induced shifts to a dechlorinating microbial community. Biotechnol Bioeng 2012, 109 (9), 2230-9.

78. Gibson, S. A.; Sewell, G. W., Stimulation of reductive dechlorination of 850 tetrachloroethene in anaerobic aquifer microcosms by addition of short-chain organic acids or alcohols. Applied and Environmental Microbiology 1992, 58 (4), 1392-1393.

79. Bouwer, E. J.; Norris, R.; Hinchee, R.; Brown, R.; McCarty, P.; Semprini, L.; Wilson, J.; Kampbell, D.; Reinhard, M.; Borden, R., Bioremediation of chlorinated solvents using alternate electron acceptors. Handbook of bioremediation. 1994, 149-175.

80. Azizian, M. F.; Marshall, I. P. G.; Behrens, S.; Spormann, A. M.; Semprini, L., Comparison of lactate, formate, and propionate as hydrogen donors for the reductive dehalogenation of trichloroethene in a continuous-flow column. Journal of Contaminant Hydrology 2010, 113 (14), 77-92.

81. Delgado, A. G.; Parameswaran, P.; Fajardo-Williams, D.; Halden, R. U.; KrajmalnikBrown, R., Role of bicarbonate as a pH buffer and electron sink in microbial dechlorination of chloroethenes. Microb. Cell Fact. 2012, 11 (1), 128. 
82. Fletcher, K. E.; Costanza, J.; Cruz-Garcia, C.; Ramaswamy, N. S.; Pennell, K. D.; Löffler, F. E., Effects of elevated temperature on Dehalococcoides dechlorination performance and DNA and RNA biomarker abundance. Environmental science \& technology 2010, 45 (2), 712-718.

870 83. Chan, W. W. M.; Grostern, A.; Löffler, F. E.; Edwards, E. A., Quantifying the Effects of 1,1,1-Trichloroethane and 1,1-Dichloroethane on Chlorinated Ethene Reductive Dehalogenases. Environmental Science \& Technology 2011, 45 (22), 9693-9702.

84. Fernandez-Sanchez, J. M.; Sawvel, E. J.; Alvarez, P. J., Effect of Fe(0) quantity on the 875 efficiency of integrated microbial-Fe(0) treatment processes. Chemosphere 2004, 54 (7), 823-9.

85. Atlas, R. M.; Philp, J. C., Bioremediation of Contaminated Soils and Aquifers. In Bioremediation Applied Microbial Solutions for Real-World Environmental Cleanup, Atlas, R. M.; Philp, J. C., Eds. ASM Press: Washington, DC, 2005; p 179.

880

86. Gu, B.; Watson, D. B.; Wu, L.; Phillips, D. H.; White, D. C.; Zhou, J., Microbiological characteristics in a zero-valent iron reactive barrier. Environ. Monitor. Assess. 2001, 77, 293-309.

87. Gregory, K. B.; Mason, M. G.; Picken, H. D.; Weathers, L. J.; Parkin, G. F., Bioaugmentation of $\mathrm{Fe}(0)$ for the remediation of chlorinated aliphatic hydrocarbons. Environ. Eng. Sci. 2000, 17 (3), 169-181.

88. Weathers, L. J.; Parkin, G. F.; Alvarez, P. J., Utilization of cathodic hydrogen as electron donor for chloroform cometabolism by a mixed, methanogenic culture. Environmental Science \& Technology 1997, 31 (3), 880-885.

890

89. Shin, K. H.; Cha, D. K., Microbial reduction of nitrate in the presence of nanoscale zerovalent iron. Chemosphere 2008, 72 (2), 257-262.

90. Son, A.; Lee, J.; Chiu, P. C.; Kim, B. J.; Cha, D. K., Microbial reduction of perchlorate with 895 zero-valent iron. Water Res. 2006, 40 (10), 2027-2032. 
91. Yu, X. Y.; Amrhein, C.; Deshusses, M. A.; Matsumoto, M. R., Perchlorate reduction by autotrophic bacteria in the presence of zero-valent iron. Environmental Science \& Technology 2006, 40 (4), 1328-1334.

900

92. Burghardt, D.; Simon, E.; Knoller, K.; Kassahun, A., Immobilization of uranium and arsenic by injectible iron and hydrogen stimulated autotrophic sulphate reduction. J. Contam. Hydrol. 2007, 94 (3-4), 305-314.

905 93. Xiu, Z. M.; Jin, Z. H.; Li, T. L.; Mahendra, S.; Lowry, G. V.; Alvarez, P. J., Effects of nanoscale zero-valent iron particles on a mixed culture dechlorinating trichloroethylene. Bioresour. Technol. 2010, 101 (4), 1141-6.

94. Lee, C.; Kim, J. Y.; Lee, W. I.; Nelson, K. L.; Yoon, J.; Sedlak, D. L., Bactericidal effect of 910 zero-valent iron nanoparticles on Escherichia coli. Environ. Sci. Technol. 2008, 42 (13), 49274933.

95. Auffan, M.; Achouak, W.; Rose, J.; Roncato, M. A.; Chaneac, C.; Waite, D. T.; Masion, A.; Woicik, J. C.; Wiesner, M. R.; Bottero, J. Y., Relation between the redox state of iron-based nanoparticles and their cytotoxicity toward Escherichia coli. Environmental Science \& Technology 2008, 42 (17), 6730-6735.

96. Li, Z. Q.; Greden, K.; Alvarez, P. J. J.; Gregory, K. B.; Lowry, G. V., Adsorbed Polymer and NOM Limits Adhesion and Toxicity of Nano Scale Zerovalent Iron to E. coli. Environmental 920 Science \& Technology 2010, 44 (9), 3462-3467.

97. Kim, J. Y.; Park, H. J.; Lee, C.; Nelson, K. L.; Sedlak, D. L.; Yoon, J., Inactivation of Escherichia coli by nanoparticulate zerovalent iron and ferrous ion. Appl. Environ. Microbiol. 2010, 76 (22), 7668-70. 
98. Sintubin, L.; De Gusseme, B.; Van der Meeren, P.; Pycke, B. F.; Verstraete, W.; Boon, N., The antibacterial activity of biogenic silver and its mode of action. Appl. Microbiol. Biotechnol.

2011.

930 99. Gavaskar, A.; Tatar, L.; Condit, W. Cost and performance report nanoscale zero-valent iron technologies for source remediation; Port Hueneme, CA, 2005.

100. McCarty, P. L.; Chu, M. Y.; Kitanidis, P. K., Electron donor and pH relationships for biologically enhanced dissolution of chlorinated solvent DNAPL in groundwater. Eur. J. Soil Biol.

$9352007,43(5-6), 276-282$.

101. Barnes, R. J.; Riba, O.; Gardner, M. N.; Singer, A. C.; Jackman, S. A.; Thompson, I. P., Inhibition of biological TCE and sulphate reduction in the presence of iron nanoparticles.

Chemosphere 2010, 80 (5), 554-62.

940

102. Kirschling, T. L.; Gregory, K. B.; Minkley, E. G., Jr.; Lowry, G. V.; Tilton, R. D., Impact of nanoscale zero valent iron on geochemistry and microbial populations in trichloroethylene contaminated aquifer materials. Environ. Sci. Technol. 2010, 44 (9), 3474-80.

945 103. Xiu, Z. M.; Gregory, K. B.; Lowry, G. V.; Alvarez, P. J., Effect of bare and coated nanoscale zerovalent iron on tce $A$ and $v c r A$ gene expression in Dehalococcoides spp. Environ. Sci. Technol. 2010, 44 (19), 7647-51.

104. Kim, H. J.; Phenrat, T.; Tilton, R. D.; Lowry, G. V., Fe-0 Nanoparticles Remain Mobile in 950 Porous Media after Aging Due to Slow Desorption of Polymeric Surface Modifiers. Environ. Sci. Technol. 2009, 43 (10), 3824-3830.

105. World Health Organization. Environmental Health Criteria 226 - Palladium; Geneva, 2002. 
106. Chidambaram, D.; Hennebel, T.; Taghavi, S.; Mast, J.; Boon, N.; Verstraete, W.; van der Lelie, D.; Fitts, J. P., Concomitant microbial generation of palladium nanoparticles and hydrogen to immobilize chromate. Environ. Sci. Technol. 2010, 44 (19), 7635-40.

960 107. De Windt, W.; Boon, N.; Van den Bulcke, J.; Rubberecht, L.; Prata, F.; Mast, J.; Hennebel, T.; Verstraete, W., Biological control of the size and reactivity of catalytic $\mathrm{Pd}^{0}$ produced by Shewanella oneidensis. Antonie Van Leeuwenhoek 2006, 90 (4), 377-89.

108. Dubilier, N., The searchlight and the bucket of microbial ecology. Environ. Microbiol. $9652007,9(1), 2-3$.

109. Kuypers, M. M. M.; Jorgensen, B. B., The future of single-cell environmental microbiology. Environ. Microbiol. 2007, 9 (1), 6-7.

970 110. Saleh-Lakha, S.; Shannon, K. E.; Goyer, C.; Trevors, J. T., Challenges in quantifying microbial gene expression in soil using quantitative reverse transcription real-time PCR. J. Microbiol. Methods 2011.

111. Mettel, C.; Kim, Y.; Shrestha, P. M.; Liesack, W., Extraction of mRNA from soil. Appl.

975 Environ. Microbiol. 2010, 76 (17), 5995-6000; Towe, S.; Wallisch, S.; Bannert, A.; Fischer, D.; Hai, B.; Haesler, F.; Kleineidam, K.; Schloter, M., Improved protocol for the simultaneous extraction and column-based separation of DNA and RNA from different soils. J. Microbiol. Methods 2011, $84(3), 406-12$.

980 112. Yergeau, E.; Lawrence, J. R.; Waiser, M. J.; Korber, D. R.; Greer, C. W., Metatranscriptomic analysis of the response of river biofilms to pharmaceutical products, using anonymous DNA microarrays. Appl. Environ. Microbiol. 2010, 76 (16), 5432-9.

113. Lee, P. K.; Johnson, D. R.; Holmes, V. F.; He, J.; Alvarez-Cohen, L., Reductive 985 dehalogenase gene expression as a biomarker for physiological activity of Dehalococcoides spp. Appl. Environ. Microbiol. 2006, 72 (9), 6161-8. 
114. Amann, R.; Fuchs, B. M., Single-cell identification in microbial communities by improved fluorescence in situ hybridization techniques. Nat. Rev. Microbiol. 2008, 6 (5), 339-48.

990

115. Fazi, S.; Aulenta, F.; Majone, M.; Rossetti, S., Improved quantification of Dehalococcoides species by fluorescence in situ hybridization and catalyzed reporter deposition. Syst. Appl. Microbiol. 2008, 31 (1), 62-67.

995 116. Lee, N.; Nielsen, P. H.; Andreasen, K. H.; Juretschko, S.; Nielsen, J. L.; Schleifer, K. H.; Wagner, M., Combination of fluorescent in situ hybridization and microautoradiography-a new tool for structure-function analyses in microbial ecology. Appl. Environ. Microbiol. 1999, 65 (3), 1289-97.

1000 117. Wang, Y.; Hammes, F.; De Roy, K.; Verstraete, W.; Boon, N., Past, present and future applications of flow cytometry in aquatic microbiology. Trends Biotechnol. 2010, 28 (8), 416-24.

118. Bouvier, T.; Del Giorgio, P. A., Factors influencing the detection of bacterial cells using fluorescence in situ hybridization (FISH): A quantitative review of published reports. FEMS

1005 Microbiol. Ecol. 2003, 44 (1), 3-15.

119. Cullen, L. G.; Tilston, E. L.; Mitchell, G. R.; Collins, C. D.; Shaw, L. J., Assessing the impact of nano- and micro-scale zerovalent iron particles on soil microbial activities: particle reactivity interferes with assay conditions and interpretation of genuine microbial effects. Chemosphere

1010 2011, 82 (11), 1675-82.

120. Krajmalnik-Brown, R.; Sung, Y.; Ritalahti, K. M.; Saunders, F. M.; Loffler, F. E., Environmental distribution of the trichloroethene reductive dehalogenase gene (tceA) suggests lateral gene transfer among Dehalococcoides. FEMS Microbiol. Ecol. 2007, 59 (1), 206-14.

121. Scheutz, C.; Durant, N. D.; Dennis, P.; Hansen, M. H.; Jorgensen, T.; Jakobsen, R.; Cox, E. E.; Bjerg, P. L., Concurrent ethene generation and growth of Dehalococcoides containing vinyl 
chloride reductive dehalogenase genes during an enhanced reductive dechlorination field demonstration. Environ. Sci. Technol. 2008, 42 (24), 9302-9.

1020

122. Baldwin, B. R.; Nakatsu, C. H.; Nies, L., Enumeration of aromatic oxygenase genes to evaluate monitored natural attenuation at gasoline-contaminated sites. Water Res. 2008, 42 (3), 723-31.

1025 123. Paszczynski, A. J.; Paidisetti, R.; Johnson, A. K.; Crawford, R. L.; Colwell, F. S.; Green, T.; Delwiche, M.; Lee, H.; Newby, D.; Brodie, E. L.; Conrad, M., Proteomic and targeted qPCR analyses of subsurface microbial communities for presence of methane monooxygenase. Biodegradation 2011.

1030 124. Reed, D. W.; Smith, J. M.; Francis, C. A.; Fujita, Y., Responses of ammonia-oxidizing bacterial and archaeal populations to organic nitrogen amendments in low-nutrient groundwater. Appl. Environ. Microbiol. 2010, 76 (8), 2517-23. 
1036 Table 1. Summary of nZVI pure culture toxicity studies.

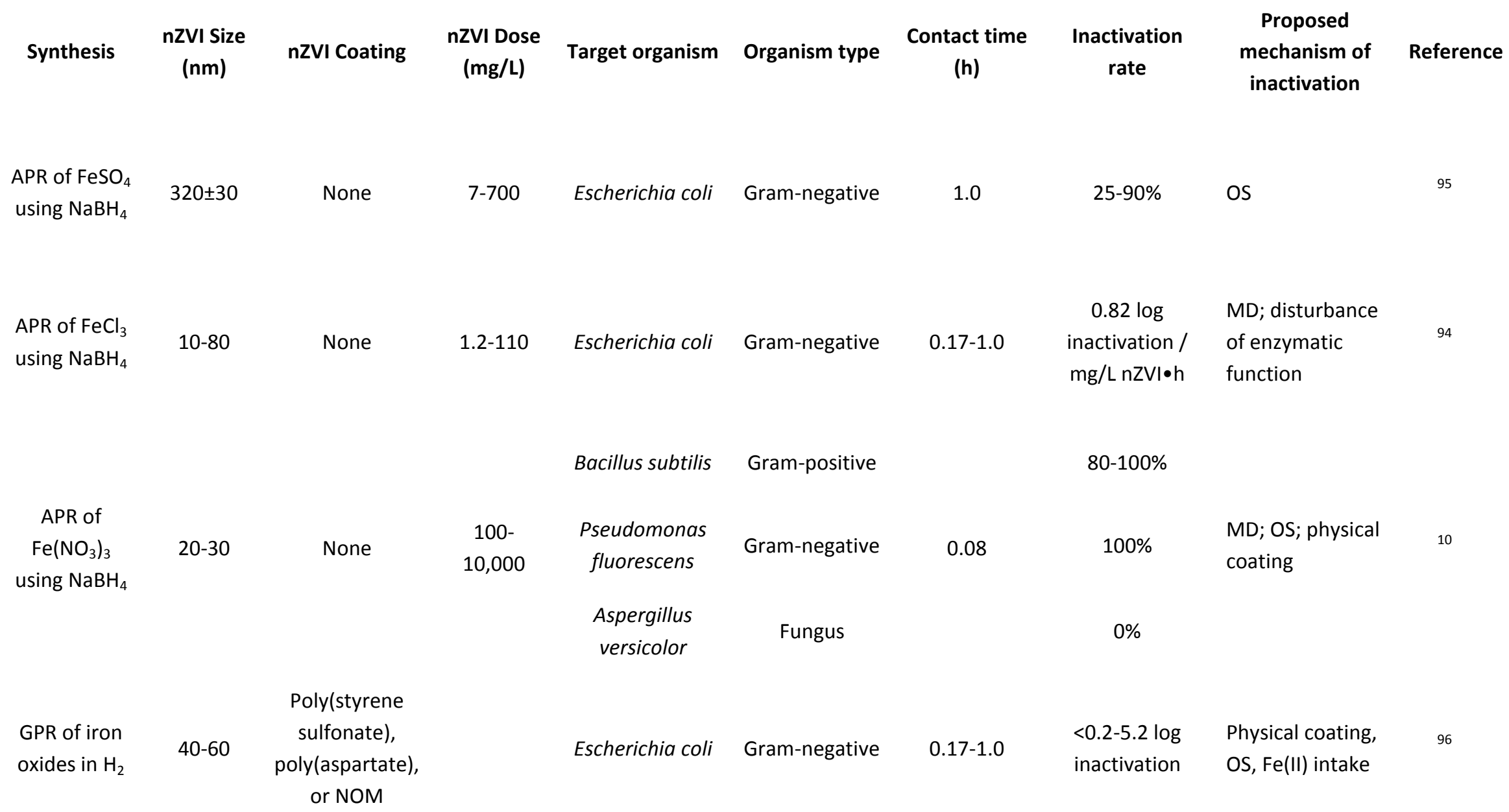


Table 2. Summary of nZVI and mixed culture microcosm studies

\begin{tabular}{|c|c|c|c|c|c|c|c|c|}
\hline Synthesis & $\begin{array}{c}\text { nZVI } \\
\text { Size (nm) }\end{array}$ & nZVI Coating & $\begin{array}{c}\text { nZVI } \\
\text { Dose (g/L) }\end{array}$ & $\begin{array}{l}\text { Sediment } \\
\text { type }\end{array}$ & $\begin{array}{l}\text { Source } \\
\text { of culture }\end{array}$ & $\begin{array}{l}\text { Duration of } \\
\text { experiment } \\
\text { (d) }\end{array}$ & $\begin{array}{c}\text { Observed effects } \\
\text { of } n Z V I\end{array}$ & Reference \\
\hline $\begin{array}{l}\text { APR of } \mathrm{FeSO}_{4} \\
\text { using } \mathrm{NaBH}_{4}\end{array}$ & $20-80$ & None & $0.01-1$ & None & $\begin{array}{l}\text { Contaminated } \\
\text { groundwater }\end{array}$ & $42-199$ & $\begin{array}{l}\text { Inhibition of DCB and DRB, } \\
\text { decreased total bacteria count, } \\
\text { lowered expression of } \\
\text { dehalogenase genes }\end{array}$ & 101 \\
\hline $\begin{array}{l}\text { GPR of iron } \\
\text { oxides in } \mathrm{H}_{2}\end{array}$ & Apr-00 & Polyaspartate & $1.5 \pm 0.1$ & $\begin{array}{l}\text { Aquifer } \\
\text { material }\end{array}$ & Aquifer material & 250 & $\begin{array}{l}\text { Changes in bacterial diversity, } \\
\text { increased total bacteria } \\
\text { abundance, stimulation of SRB } \\
\text { and methanogens by } \mathrm{H}_{2} \text { and } \\
\text { polyaspartate }\end{array}$ & 102 \\
\hline $\begin{array}{l}\text { GPR of iron } \\
\text { oxides in } \mathrm{H}_{2}\end{array}$ & $\begin{array}{l}\text { 5-70 (mean } \\
\quad=20)\end{array}$ & $\begin{array}{l}\text { Olefin maleic } \\
\text { acid copolymer }\end{array}$ & 1 & None & $\begin{array}{l}\text { Laboratory } \\
\text { enrichment }\end{array}$ & 7 & $\begin{array}{l}\text { Downregulation of reductive } \\
\text { dehalogenase genes by } \\
\text { uncoated nZVI, this effect } \\
\text { mitigated by addition of } \\
\text { polymer coating to nZVI }\end{array}$ & 103 \\
\hline $\begin{array}{l}\text { GPR of iron } \\
\text { oxides in } \mathrm{H}_{2}\end{array}$ & $40-60$ & None & 1 & None & $\begin{array}{l}\text { Laboratory } \\
\text { enrichment }\end{array}$ & 71 & $\begin{array}{l}\text { Stimulation of methanogens, } \\
\text { initial (but temporary) inhibition } \\
\text { of dechlorinating bacteria }\end{array}$ & 93 \\
\hline $\begin{array}{l}\text { Ball-milling of } \\
\text { microscale ZVI }\end{array}$ & $12.5 \pm 0.3$ & Polyacrylic acid & 10 mg/g & $\begin{array}{c}\text { Surface } \\
\text { soil }\end{array}$ & Surface soil & 14 & $\begin{array}{l}\text { No impact on dehydrogenase or } \\
\text { hydrolase levels, no impact on } \\
\text { ammonia oxidation potential }\end{array}$ & 119 \\
\hline
\end{tabular}


1040 Table 3. Functional targets for qualitative analysis of microbiota in organics-contaminated 1041 aquifers

1042

\begin{tabular}{|c|c|c|c|c|}
\hline Contaminant & Functional target & Gene & Technique & Reference \\
\hline \multirow[t]{2}{*}{ TCE } & Trichloroethene reductive dehalogenase & $t c e A$ & qPCR & 103 \\
\hline & Trichloroethene reductive dehalogenase & tce $B$ & qPCR & 120 \\
\hline VC & Vinyl chloride reductive dehalogenase & vcrA & qPCR & 121 \\
\hline Phenol & Phenol hydroxylase & phe & qPCR & 121 \\
\hline Napthalene & Napthalene dioxygenase & nah & qPCR & 122 \\
\hline \multirow[t]{3}{*}{ Toluene } & Toluene monoxygenase & tom & qPCR & 122 \\
\hline & Toluene dioxygenase & tod & qPCR & 122 \\
\hline & Ring-hydroxylating toluene monooxygenase & rmo & qPCR & 122 \\
\hline Biphenyls & Biphenyl dioxygenase & $b p h$ & qPCR & 122 \\
\hline \multirow[t]{3}{*}{ Organics } & Soluble methane monooxygenase & $\operatorname{mmoX}$ & qPCR / proteomics & 123 \\
\hline & Particulate methane monooxygenase & $p m o A$ & qPCR / proteomics & 123 \\
\hline & Ammonia monooxygenase & $a m o A$ & qPCR & 124 \\
\hline
\end{tabular}

*Indicates study in which ZVI was used. 


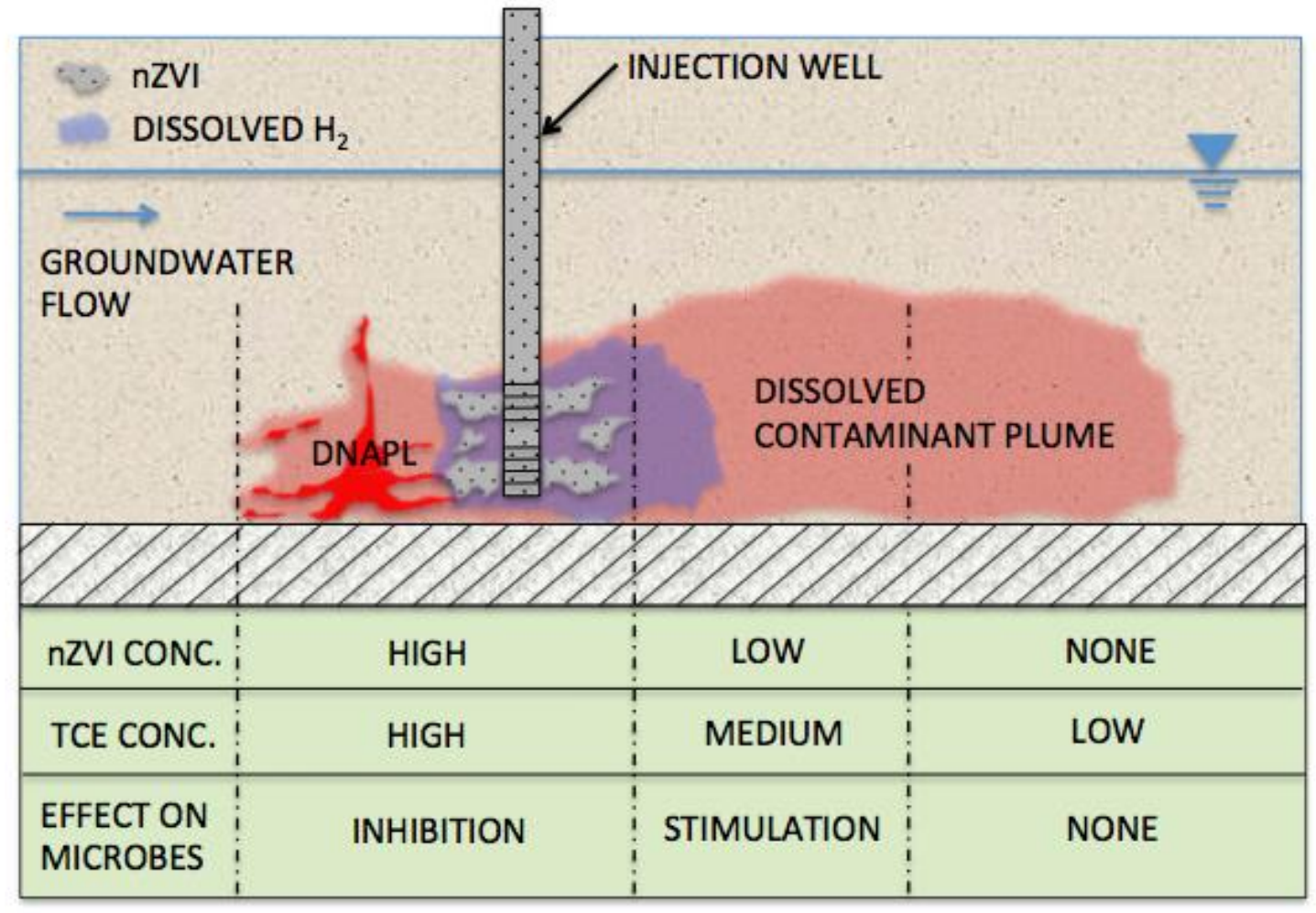

1052 Figure 1: Conceptual model of nZVI injection in DNAPL source zone and effects on microbial 1053 community. 